\title{
A Wideband Conductor Backed Coplanar Waveguide Fed Implantable Antenna Operable in Different Tissues for Biotelemetry Applications
}

\author{
Tayfun OKAN \\ Dept. of Electrical-Electronic Engineering, Engineering Faculty, Gazi University, \\ Eti Mh. Yukselis Sk. No: 5, 06570, Maltepe / Ankara-Turkey \\ tayfunokan@gmail.com \\ Submitted July 15, 2020 / Accepted March 9, 2021
}

\begin{abstract}
A$ wideband biocompatible implanted antenna is designed for wireless biotelemetry applications at industrial, scientific and medical (ISM) band (2.4-2.48 GHz). The antenna is fed by a conductor backed coplanar waveguide $(C B-C P W)$ structure and two H-shaped slots are etched side by side on the patch of the antenna to create a resonance at the desired frequency. The experimental and simulation measurements are performed by using skin, fat and muscle tissue layers. The impedance bandwidth $\left(S_{11} \leq-10 \mathrm{~dB}\right)$ of the proposed antenna is measured as $0.406 \mathrm{GHz}(2.272-2.678 \mathrm{GHz})$, when the fabricated antenna is implanted inside a three-layered human body mimicking gel. By using the advantage of having a wide bandwidth, the designed antenna is analyzed inside different tissue types and tissue thicknesses. For every obtained simulation and experimental result, it is observed that the antenna always covers the ISM band, which is the most significant contribution of this study. The size of the implantable antenna is $16 \times 13 \times 1.93 \mathrm{~mm}^{3}$, where both sides of the antenna are covered by a superstrate material to extend the life of the antenna inside the tissue.
\end{abstract}

\section{Keywords}

Biomedical applications, coplanar waveguide (CPW), implantable antennas, industrial scientific medical (ISM) band

\section{Introduction}

With the parallel developments in wireless communications and biomedical technologies, researchers have been studying to improve the quality of human life [1], [2] and patient health care [3]. A variety of studies on miniaturized electrically small in-body antennas have been performed to contribute to these progresses. At first, low frequency RF based communication systems were used in the past for several biomedical applications. However, these systems were limited with their low data rate and short range disad- vantages. Therefore, the necessity to announce other frequency bands by International Electrotechnical Commission (IEC) and Federal Communications Commission (FCC) was arisen. As a result, studies started to concentrate at Medical Implant Communication Service (MICS) band (402-405 MHz), and Industrial, Scientific and Medical (ISM) band (2.4-2.48 GHz) [4], [5].

It is a challenging process to design an antenna that is capable of operating inside human tissue. First and foremost, the implanted antenna should be biocompatible not to harm patient's health and also to prevent the implant from any rejection [6]. Secondly, attention should be paid to prevent any direct contact with the copper part of the antenna that might create short circuit. Therefore, a superstrate material is installed for a proper isolation, especially for the antenna elements that are intended to be used for long-terms. Impedance matching, radiation characteristic, small size, low power requirement are other important factors that play a major role in this design process [7].

Implanted antennas are generally designed to operate in a specific tissue type; because each tissue has a different water content, permittivity and conductivity value that directly affect the bandwidth, radiation pattern and efficiency of the antenna [8], [9]. However, a wideband antenna is less likely to be affected by the variation of tissue thickness [10]. Furthermore, the effect of the electromagnetic field generated by the antenna on the surrounding tissue should be low in order to prevent any damage to human body.

A compact dual band antenna was reported in [11] where the antenna was consisted of spiral and anti-spiral resonators. In [12], planar f-inverted antennas (PIFA) were designed by spiral and serpentine shapes to operate in MICS band, and a silicon based material was used in this study as a superstrate. Kumar et al. designed coplanar waveguide (CPW) fed slot antennas operable in ISM band in [13] and [14], where in vivo and in vitro radiation characteristics were analyzed, respectively. Apart from the regular design, the bended version of the proposed antenna was also analyzed in [15]. Besides that, specific absorption 
rate (SAR) measurement of the antenna that operated in ISM band was also performed and the results seemed to fulfill the necessary regulations. A mimicking gel was created in [16] to perform the in vitro measurements for the reported dual band antenna which was designed to be used for continuous glucose monitoring. In [17] and [18] the performance of the presented biocompatible implanted antennas was reported when the antennas were embedded inside the chest part of a voxel model and inside an arm, respectively. Furthermore, in some other studies [5, 19, 20] multi band antennas were presented that operate in different frequencies beside the ISM band.

Different PIFA designs have been used in most of the aforementioned studies [12, 21, 22]. Apart from its advantages, PIFA has a major disadvantage of having a narrow bandwidth. Despite that, a CPW fed antenna offers several advantages such as broadband performance and low dispersion [23]. In this study, a conductor backed coplanar waveguide (CB-CPW) fed monopole antenna is proposed to be used as an in-body antenna. The feeding technique in this paper is referred as CB-CPW, but not as grounded coplanar waveguide (GCPW); since plated through holes or in other words vias do not appear in the proposed design. Moreover, the most important contribution of this work is that the wideband feature of the proposed antenna provides it to be able to operate in different tissue types and different depth of tissue. Computer based simulations are performed by using CST Microwave Studio, and the experimental measurements are made by fabricating the presented antenna and implanting it inside human tissue mimicking gels.

\section{Antenna Design}

The proposed CB-CPW fed implanted antenna consists of a rectangular shaped radiator and a ground plane on the other side of the substrate as shown in Fig. 1. Grey parts in Fig. 1(a) represent the substrate, while the yellow parts represent the copper that has a thickness of $0.035 \mathrm{~mm}$. The length and width of the radiator patch is chosen by considering the conventional equations in antenna theory for common patch antennas [23]. But as the designed antenna is not planned to operate at free space, these values need to be modified with respect to the tissue type and thickness it is implemented in. As the designed antenna is planned to be used inside human body, it also needs to be covered with a superstrate for a proper isolation. The signal of the antenna is strongly attenuated as it is used inside human body and covered by a superstrate material. Hence, the exact size of the radiator patch is determined by tryand-error method.

Two vertically positioned H-shaped slots are etched side by side on the patch of the antenna. The width and length of these slots are selected in order to catch the desired resonance frequency at $2.45 \mathrm{GHz}$. Moreover, a sufficient amount of gap is left between upper ground plane and signal line to avoid any problem that might occur during the soldering process of SMA connector. That gap is la- beled as $W_{8}$, which is $0.5 \mathrm{~mm}$. A narrow slit with a width of $0.2 \mathrm{~mm}$ and length of $1.5 \mathrm{~mm}$ is introduced on each side of the signal line. A slit is used in the design to feed the patch closer to the center and provide a better impedance matching. Furthermore, to match the characteristic impedance of $50 \Omega$, the signal line has length and width of $7.5 \mathrm{~mm}$ and $1.3 \mathrm{~mm}$, respectively. The antenna is printed on a Rogers RO3210 substrate material, this material is preferred as it is biocompatible. It has a permittivity of 10.2, a loss tangent of 0.0027 and a thickness $(T)$ of $0.62 \mathrm{~mm}$. Since this antenna is implanted inside human body and every tissue of human body has a certain water content, the antenna needs to be covered with a superstrate material in order to prevent any short circuit. Although a variety of materials like silicon $\left(\varepsilon_{\mathrm{r}}=11.7\right)$, Teflon $\left(\varepsilon_{\mathrm{r}}=2.1\right)$, Macor $\left(\varepsilon_{\mathrm{r}}=6.1\right)$, PEEK $\left(\varepsilon_{\mathrm{r}}=3.2\right)$, Alumina $\left(\varepsilon_{\mathrm{r}}=9.4\right)$, and zirconia $\left(\varepsilon_{\mathrm{r}}=29\right)$ can be used as a superstrate material, the same RO3210 is preferred to be used with a thickness $\left(T_{\text {sup }}\right)$ of $0.62 \mathrm{~mm}$ as the superstrate, due to its biocompatible property. Both the top and bottom side of the designed antenna is covered with the superstrate material in this study. The optimum antenna dimensions to obtain a resonance at the desired frequency and a wide impedance bandwidth $\left(\mathrm{S}_{11} \leq-10 \mathrm{~dB}\right)$ are given in Tab. 1, where the total size of the antenna is $16 \times 13 \times 1.93 \mathrm{~mm}^{3}(0.13 \lambda \times 0.104 \lambda \times 0.016 \lambda$, where $\lambda$ is the wavelength at the lowest operating frequency). The EM simulation analyses in the following parts are made by using CST Microwave Studio.

A parametric study is performed to analyze the effect of some parameters on antenna performance. The length of the bottom ground plane $\left(L_{\mathrm{g}}\right)$ has a major effect on impedance bandwidth of the antenna. As seen in Fig. 2(a), three different $L_{\mathrm{g}}$ values are illustrated and the best performance
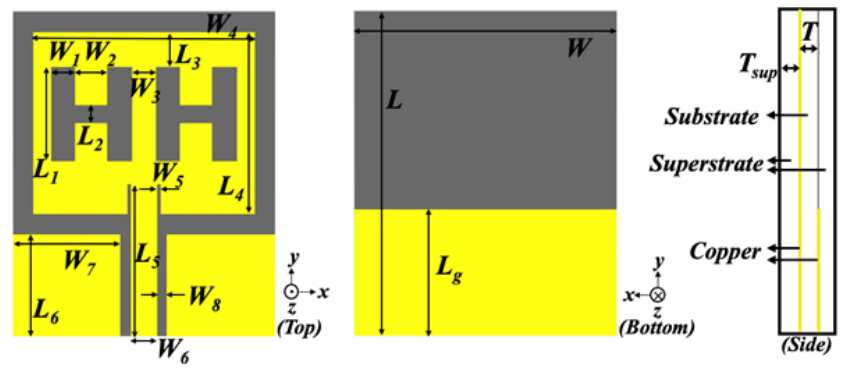

(a)

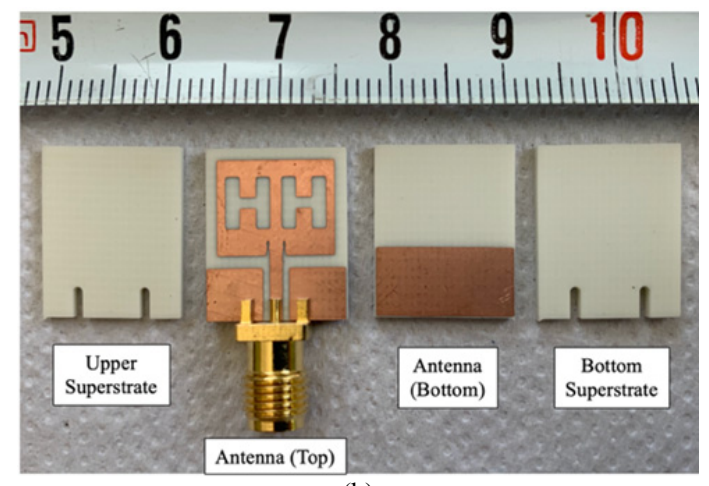

(b)

Fig. 1. Geometrical configuration of the proposed antenna design: (a) simulated and (b) fabricated. 


\begin{tabular}{|l|c|c|c|c|c|c|}
\hline Parameter & $W$ & $L$ & $W_{1}$ & $W_{2}$ & $W_{3}$ & $W_{4}$ \\
\hline Value (mm) & 13 & 16 & 1.2 & 1.6 & 1.2 & 11 \\
\hline Parameter & $W_{5}$ & $W_{6}$ & $W_{7}$ & $W_{8}$ & $L_{1}$ & $L_{2}$ \\
\hline Value (mm) & 0.2 & 1.3 & 5.3 & 0.5 & 4.7 & 0.9 \\
\hline Parameter & $L_{3}$ & $L_{4}$ & $L_{5}$ & $L_{6}$ & $L_{\mathrm{g}}$ & $T_{\text {sup }}$ \\
\hline Value (mm) & 1.7 & 9 & 7.5 & 5 & 6.6 & 0.62 \\
\hline
\end{tabular}

Tab. 1. Dimensions of the antenna element.

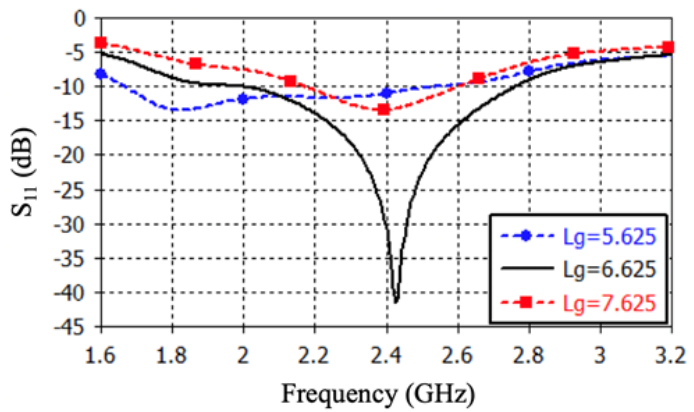

(a)

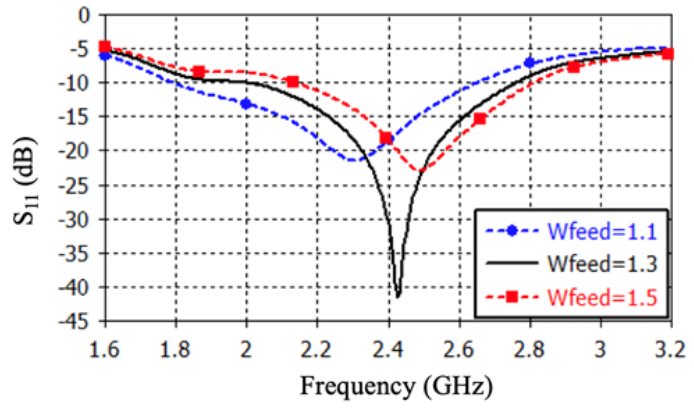

(b)

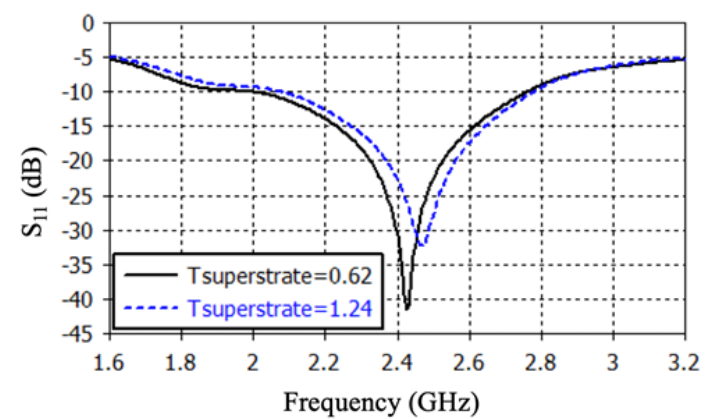

(c)

Fig. 2. The effect of (a) $L_{\mathrm{g}}$, (b) $W_{\text {feed }}$ and (c) $T_{\text {superstrate }}$ on reflection coefficient.

is reached with $6.6 \mathrm{~mm}$. Signal line width is another parameter that plays a critical role on reflection coefficient. The effect of the variation in the width of the signal line is depicted in Fig. 2(b), where $W_{\mathrm{f}}$ value is set to $1.3 \mathrm{~mm}$ to match the characteristic impedance of $50 \Omega$. Finally, the effect of the thickness of the superstrate material in the optimization of operating bandwidth is analyzed in Fig. 2(c), where the best reflection coefficient result is obtained with $0.62 \mathrm{~mm}$ thickness of RO3210.

\section{Simulations and Experimental Measurements}

Under this title, the performance of the proposed antenna is analyzed with both experimental measurements and simulation results. For the experimental part, in vitro measurements are performed and the characteristic of the antenna is investigated under a three layered body model. The simulation and experimental setup used in this study to perform the necessary analyses of the proposed antenna is shown in Fig. 3. The three-layer human body model consists of skin, fat and muscle layers; where the thickness of each layer is selected as 4,7 and $10 \mathrm{~mm}$, respectively. The antenna, top and bottom of which is covered with superstrate, is implanted to the bottom part of the fat tissue for both simulation and experimental measurements. An edge mount SMA end launch connector is used not only in experimental measurements but also throughout the simulations, where relevant data and simulation model are provided from the vendor. The connector used in this study can support up to $18 \mathrm{GHz}$, which is well above the operating frequency of the proposed antenna. Furthermore, a Rohde \& Schwarz ZVB14 VNA is used in the measurements, which is capable of measuring up to $14 \mathrm{GHz}$.

For in vitro testing of the antenna, human tissue mimicking gels are prepared by using the components given in Tab. 2 [9], [13]. One important point is that these

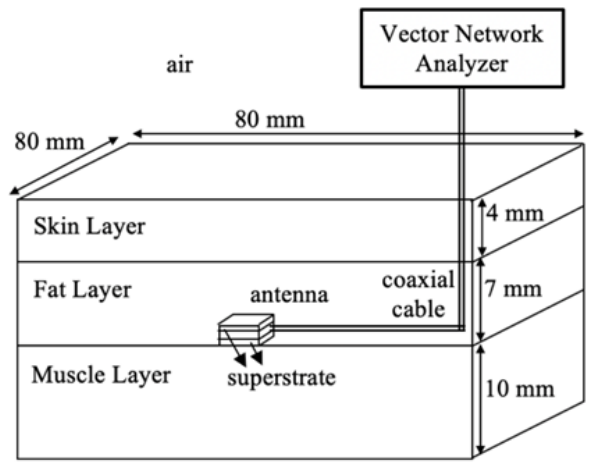

(a)

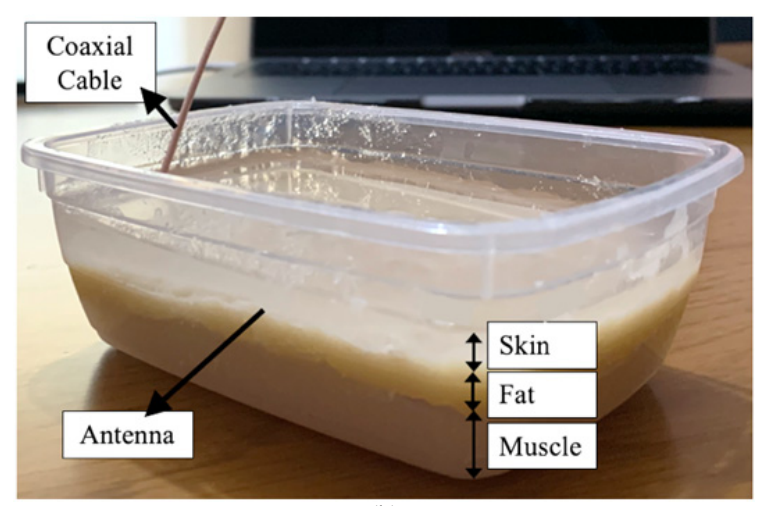

(b)

Fig. 3. The three layered setup used for (a) simulation and (b) experimental measurements. 
ratios are determined with respect to the operating frequency value, which is $2.45 \mathrm{GHz}$ for this study. Flour and vegetable oil are used to form the fat mimicking gel. Although Agarose is generally used to solidify the liquid phantom in the studies available in literature, Carbomer is preferred in this study to ensure the formation of the gel. As seen in Tab. 2, $0.5 \mathrm{~g}$ of Carbomer is added per $40 \mathrm{ml}$ of mimicking gel to form skin and muscle tissues. After adding Carbomer to the liquid solution, the mixture is heated to make it homogeneous by stirring well at around $60-70^{\circ} \mathrm{C}$. The mixture is then cooled to room temperature and Triethanolamine (TEA) is added until the desired gel texture is formed. Afterwards, the mimicking gels are poured into a plastic container that has a size of $80 \times 80 \mathrm{~mm}^{2}$. During this process, it is important to prevent any bubbles and air gaps that might occur for proper measurement. Another important issue is that the experimental measurements should be performed right after forming the tissue mimicking gels. Because deionized water is used to form the skin, fat and muscle mimicking phantoms; and its evaporation should be prevented not to disrupt the structural form and characteristic of the phantom.

For the simulation part, again the three layered body model consisting of skin, fat and muscle is created in the simulation platform, with thicknesses of 4,7 and $10 \mathrm{~mm}$, respectively. The antenna is positioned at the bottom part of the fat tissue and it is excited by a SMA connector. Figure 4 represents the simulated and measured reflection coefficient graphs of the proposed antenna. Both of these reflection coefficient results cover the ISM band, where $\left(\mathrm{S}_{11} \leq-10 \mathrm{~dB}\right)$. The antenna has an impedance bandwidth of $0.77 \mathrm{GHz}(1.99 \mathrm{GHz}$ to $2.76 \mathrm{GHz})$ with respect to simulation results, and $0.406 \mathrm{GHz}(2.272 \mathrm{GHz}$ to $2.678 \mathrm{GHz})$ with respect to the experimental measurements. Moreover, the antenna has a resonance frequency at $2.425 \mathrm{GHz}$ with the reflection coefficient value of $-41.5 \mathrm{~dB}$.

The two of the biggest goals of this study is to design an implantable antenna that can operate inside tissues that have different thicknesses, and that can operate inside different tissue types. In Fig. 5(a), a variety of thickness combinations are used and their effects on reflection coefficient results are analyzed. The thickness of skin layer is changed as 2 and $4 \mathrm{~mm}$; fat layer is changed as 5, 7 and $9 \mathrm{~mm}$; and muscle layer thickness is varied as 10,15 and $20 \mathrm{~mm}$. The combination of these values creates 18 results and all these reflection coefficient results are plotted in Fig. 5(a), where in all simulations the antenna is positioned between fat and

\begin{tabular}{|l|c|c|c|}
\hline & Skin & Fat & Muscle \\
\hline Deionized water & $50 \%$ & $2.9 \%$ & $59.5 \%$ \\
\hline $\mathrm{NaCl}$ & - & $0.1 \%$ & $0.5 \%$ \\
\hline Sugar & $50 \%$ & - & $40 \%$ \\
\hline Vegetable oil & - & $30 \%$ & - \\
\hline Flour & - & $67 \%$ & - \\
\hline Carbomer & $0.5 \mathrm{~g} / 40 \mathrm{ml}$ & - & $0.5 \mathrm{~g} / 40 \mathrm{ml}$ \\
\hline
\end{tabular}

Tab. 2. The amount and type of materials used to create the phantom model at $2.45 \mathrm{GHz}$ [9], [13].

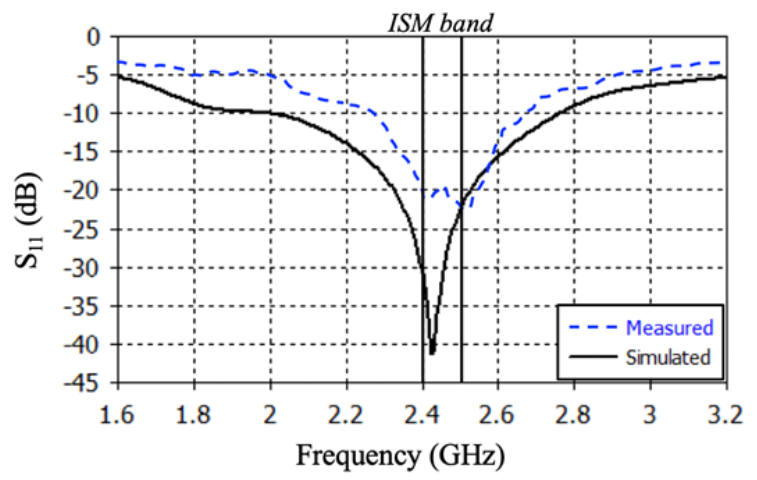

Fig. 4. Measured and simulated reflection coefficient of the proposed antenna.

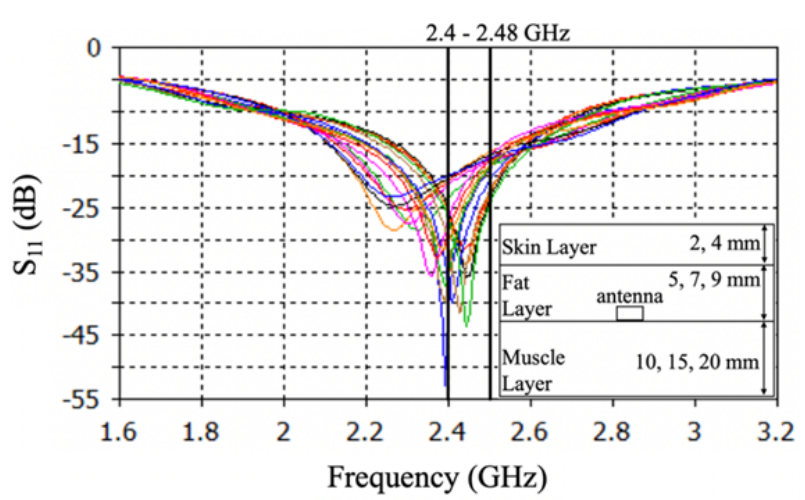

(a)

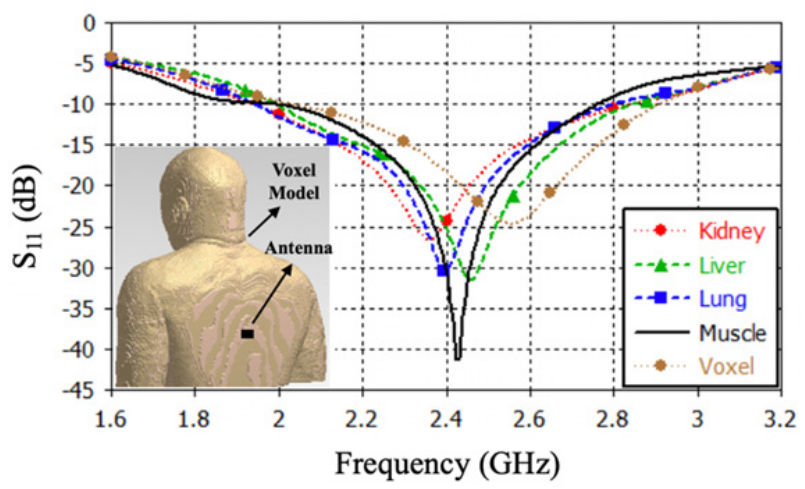

(b)

Fig. 5. The change in reflection coefficient for (a) different thickness values of skin, fat and muscle layers, (b) different human tissue types and voxel model.

muscle layers. It can be seen that each result covers the ISM band $(2.4-2.48 \mathrm{GHz})$ in its operating bandwidth, thanks to the wideband characteristic of the proposed antenna. Furthermore, another analysis is performed to confirm the operability of the antenna inside different tissue types. Therefore; kidney, liver and lung (deflated) tissues are used in the simulations, besides the muscle tissue. Although these four tissues have the same thickness of $20 \mathrm{~mm}$, they have different dielectric constant and conductivity values as seen in Tab. 3 [15]. This causes a difference in signal attenuation and antenna performance. In addition to that, a human body voxel model is also used where the antenna is implanted on the back of the voxel. In each scenario, the reflection coefficient outputs give satisfactory results and cover the ISM band, as seen in Fig. 5(b). 
Three layered skin, fat and muscle tissue configuration is used with thicknesses of 4,7 and $10 \mathrm{~mm}$, respectively for all the following simulations. Furthermore, the antenna is positioned at the bottom part of the fat tissue. The simulated radiation patterns of the proposed antenna are shown in Fig. 6. The one on the left shows the E-plane (xz-plane) results and the one on the right depicts the $H$ plane (yz-plane) measurements at the resonance frequency of $2.42 \mathrm{GHz}$. As seen from the results, the co-polarized fields in both $E$ and $H$-planes have isotropic radiation patterns; whereas, the cross-polarized field in $E$-plane has omni-directional radiation characteristic. The cross-polarized level in $H$-plane is too small to appear in the graph, as it is below $-100 \mathrm{~dB}$.

\begin{tabular}{|c|c|c|c|c|}
\hline $\begin{array}{c}\text { Tissue } \\
\text { Type }\end{array}$ & $\begin{array}{c}\text { Dielectric } \\
\text { Constant }\end{array}$ & $\begin{array}{c}\text { Conductivity } \\
(\mathbf{S} / \mathbf{m})\end{array}$ & $\begin{array}{c}\text { Density } \\
\left(\mathbf{k g} / \mathbf{m}^{\mathbf{3}}\right)\end{array}$ & $\begin{array}{c}\text { Thick. } \\
(\mathbf{m m})\end{array}$ \\
\hline Skin layer & 38 & 1.46 & 1010 & 2,4 \\
\hline Fat layer & 5.28 & 0.1 & 920 & $5,7,9$ \\
\hline $\begin{array}{c}\text { Muscle } \\
\text { layer }\end{array}$ & 52.7 & 1.73 & 1040 & $\begin{array}{c}10,15, \\
20\end{array}$ \\
\hline Liver layer & 43 & 1.68 & 1076 & 20 \\
\hline $\begin{array}{c}\text { Lung layer } \\
\text { (Deflated) }\end{array}$ & 48.38 & 1.68 & 1050 & 20 \\
\hline $\begin{array}{c}\text { Kidney } \\
\text { layer }\end{array}$ & 52.74 & 2.43 & 1068 & 20 \\
\hline
\end{tabular}

Tab. 3. Tissue properties and parameters of the human body at $2.45 \mathrm{GHz}$.

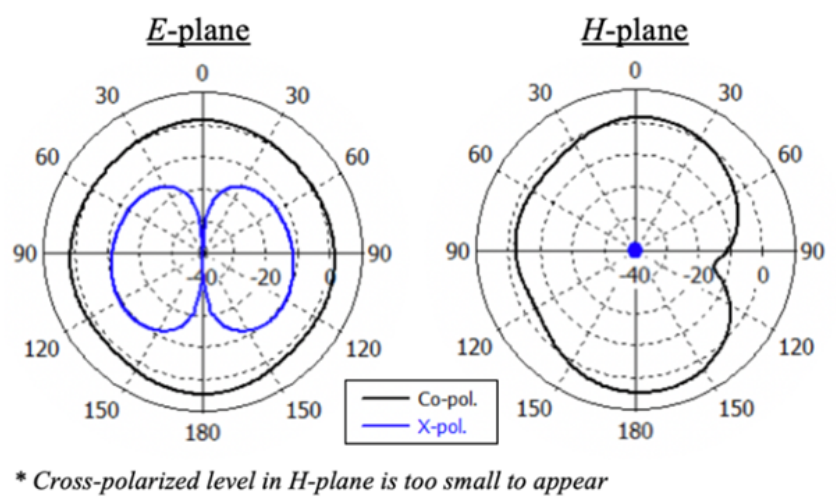

Fig. 6. The simulated radiation patterns of the antenna for $E$-plane and $H$-plane at $2.42 \mathrm{GHz}$.

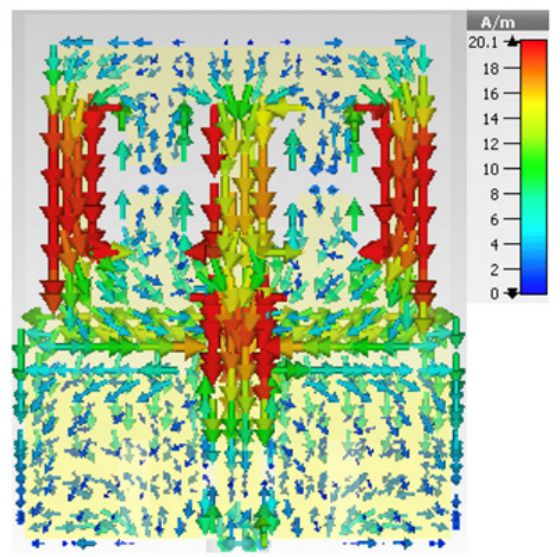

Fig. 7. Surface current distribution of the antenna at $2.42 \mathrm{GHz}$
The vectoral surface current distribution of the proposed antenna at $2.42 \mathrm{GHz}$ and $0^{\circ}$ phase value is shown in Fig. 7. As seen from the figure, the surface currents are mainly concentrated especially at the side edges of the $\mathrm{H}$ shaped slot. Besides the bottom edge of the radiator patch, the current density at the connection of the feeding line and the patch is also high.

The effect of the electromagnetic field generated by the antenna on the surrounding tissue should be low in order to prevent any damage to human body. Hence; the SAR value, which is a measure of how transmitted RF energy is absorbed by human tissue, should not exceed $1.6 \mathrm{~W} / \mathrm{kg}$ for $1 \mathrm{~g}$ of averaging tissue or $2 \mathrm{~W} / \mathrm{kg}$ for $10 \mathrm{~g}$ of averaging tissue in FCC and IEC standards, respectively [11]. The numerical SAR measurement at the resonance frequency is performed for $1 \mathrm{~g}$ of tissue with IEEE C95.3 averaging method for the delivered input power of $1 \mathrm{~mW}$. As seen in Fig. 8, the maximum SAR distributions are observed at the middle part of the sample tissue and the peak SAR value is obtained as $0.312 \mathrm{~W} / \mathrm{kg}$ at the surface of the antenna, which is within the limit. This SAR specification is an important design consideration in the design process of an implantable antenna.

Human body has a curved structure, especially close to the articular regions. Besides that, it is very likely for any part of human tissue to take a curved form while in motion. Therefore, the designed antenna should be verified to operate properly in bent conditions. For that reason, the proposed antenna and the tissues in which it is placed are

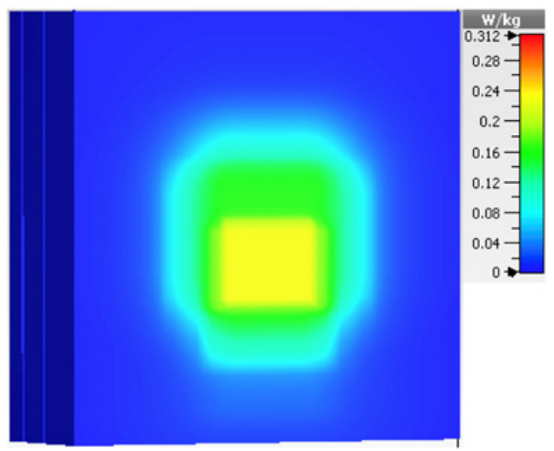

Fig. 8. SAR measurement of the proposed antenna on human body model.

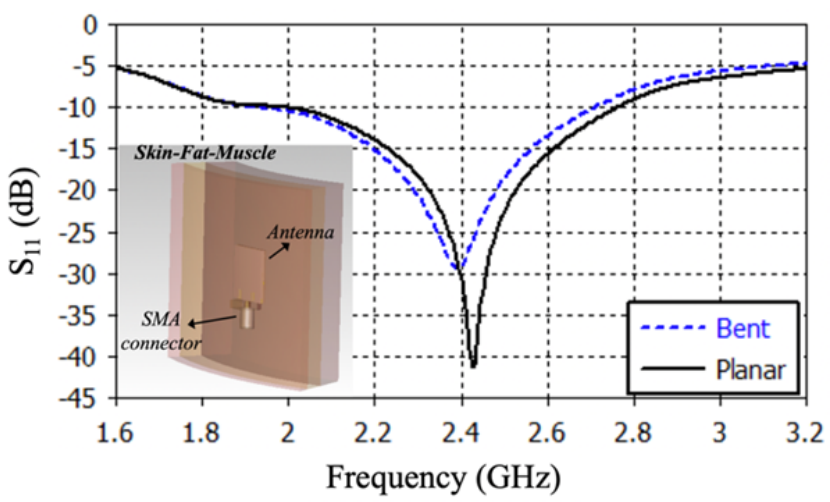

Fig. 9. Reflection coefficient measurements for bent and planar antennas. 


\begin{tabular}{|c|c|c|c|c|}
\hline Study & $\begin{array}{c}\text { Bandwidth } \\
(\mathbf{G H z})\end{array}$ & $\begin{array}{c}\text { Size } \\
\left(\mathbf{m m}^{2}\right)\end{array}$ & $\begin{array}{c}\text { Substrate } \\
\text { material }\end{array}$ & $\begin{array}{c}\text { Experimental } \\
\text { setup }\end{array}$ \\
\hline$[5]$ & 0.05 & $70 \times 60$ & $\begin{array}{c}\text { FR-4 } \\
\left(\varepsilon_{\mathrm{r}}=4.4\right)\end{array}$ & $\begin{array}{c}\text { In vitro } \\
(1 \text { layer })\end{array}$ \\
\hline$[6]$ & 0.04 & $22 \times 18$ & $\begin{array}{c}\text { FR-4 } \\
\left(\varepsilon_{\mathrm{r}}=4.5\right)\end{array}$ & $\begin{array}{c}\text { Only } \\
\text { simulation }\end{array}$ \\
\hline$[11]$ & 0.36 & $15 \times 15$ & $\begin{array}{c}\text { RO3210 } \\
\left(\varepsilon_{\mathrm{r}}=10.2\right)\end{array}$ & Free space \\
\hline$[13]$ & 0.22 & $14 \times 10$ & $\begin{array}{c}\text { Alumina } \\
\left(\varepsilon_{\mathrm{r}}=9.8\right)\end{array}$ & $\begin{array}{c}\text { In vitro } \\
(3 \text { layer })\end{array}$ \\
\hline$[14]$ & 0.21 & $29 \times 29$ & $\begin{array}{c}\text { RO3210 } \\
\left(\varepsilon_{\mathrm{r}}=10.2\right)\end{array}$ & $\begin{array}{c}\text { In vitro } \\
(3 \text { layer })\end{array}$ \\
\hline$[15]$ & 0.350 & $25.9 \times 25.5$ & $\begin{array}{c}\text { PDMS } \\
\left(\varepsilon_{\mathrm{r}}=2.2\right)\end{array}$ & $\begin{array}{c}\text { In vitro } \\
(1 \text { layer })\end{array}$ \\
\hline$[16]$ & 0.18 & $22.5 \times 22.5$ & $\begin{array}{c}\text { RO3210 } \\
\left(\varepsilon_{\mathrm{r}}=10.2\right)\end{array}$ & $\begin{array}{c}\text { In vitro } \\
(1 \text { layer })\end{array}$ \\
\hline$[19]$ & 0.163 & $74 \times 30$ & $\begin{array}{c}\mathrm{FR}-4 \\
\left(\varepsilon_{\mathrm{r}}=4.4\right)\end{array}$ & NA \\
\hline$[20]$ & 0.12 & $14 \times 12$ & $\begin{array}{c}\text { RO3210 } \\
\left(\varepsilon_{\mathrm{r}}=10.2\right)\end{array}$ & $\begin{array}{c}\text { In vitro } \\
(1 \text { layer })\end{array}$ \\
\hline$[22]$ & 0.09 & $8 \times 6$ & $\begin{array}{c}\text { RO3210 } \\
\left(\varepsilon_{\mathrm{r}}=10.2\right)\end{array}$ & $\begin{array}{c}\text { Only } \\
\text { simulation }\end{array}$ \\
\hline Proposed & 0.406 & $16 \times 13$ & $\begin{array}{c}\text { RO3210 } \\
\left(\varepsilon_{\mathrm{r}}=10.2\right)\end{array}$ & $\begin{array}{c}\text { In vitro } \\
(3 \text { layer })\end{array}$ \\
\hline
\end{tabular}

Tab. 4. Comparison table with other in-body ISM band antennas.

bent around the $y$-axis by using a $10 \mathrm{~cm}$ diameter cylinder to analyze the designed antenna in bent condition. Figure 9 represents the reflection coefficient of bent and planar antenna on the same graph. It depicts that the $S_{11}$ value of the bent antenna is $-29.39 \mathrm{~dB}$ at the resonance frequency of $2.39 \mathrm{GHz}$. The bandwidth of $790 \mathrm{MHz}$ is maintained and the complete ISM band is still covered.

A comparison is made with other state-of-arts in Tab. 4 to better validate the merit of the performed work. Since in-body MICS band antennas tend to have narrower bandwidths [11], [16], the comparison list consists of antennas operating in the ISM band to make a fair comparison. Therefore, the values indicated in the table show the bandwidths in the ISM band. As seen from the table, the proposed antenna has the best bandwidth performance and has the smallest size except the antennas in [13, 20, 22]. Moreover, this study is one of the very few studies where a three layered human body model (skin, fat, muscle mimicking gels) is used in the experimental measurements. Using a three separate layer mimicking gel is important; as the most realistic results are achieved with such setup.

\section{Conclusion}

The design, fabrication and measurement of a wideband CB-CPW fed implantable antenna is analyzed for the ISM band. Although superstrate material is used on both sides of the antenna, it has a small size with the overall dimensions of $16 \times 13 \times 1.93 \mathrm{~mm}^{3}$. It is observed with this study that, unlike the other state-of-arts, the proposed antenna is usable for different tissue thicknesses and for different tissue types, thanks to its wide bandwidth. This usability is also confirmed as the antenna is simulated inside a human body voxel model. Moreover, the fabricated antenna is tested for in vitro measurements; where all three skin, fat and muscle tissues are mimicked with a phantom gel separately for a more realistic measurement. All the obtained simulation and experimental results show great agreement with each other, and the wideband characteristic of the proposed antenna is confirmed. To analyze the amount of electromagnetic radiation that the human tissue covering the implanted antenna is exposed, numerical SAR measurement is performed with the simulation setup. It is observed that the obtained SAR values are within the FCC and IEC limits.

\section{References}

[1] TARbOUCH, M., EL AMRI, A., TERCHOUnE, H. Compact CPW-Fed microstrip octagonal patch antenna with $\mathrm{H}$ slot for WLAN and WIMAX applications. In Proceedings of the International Conference on Wireless Technologies, Embedded and Intelligent Systems (WITS). Fez (Morocco), 2017, p. 1-6. DOI: 10.1109/WITS.2017.7934638

[2] SHARMA, S., SAXENA, V. N., GOODWILL, K., et al. CPW fed rectangular slot antenna with dual $\mathrm{H}$-slot on ground for wideband wireless applications. In Proceedings of the International Conference on Signal Processing and Communication. Noida (India), 2015, p. 439-442. DOI: 10.1109/ICSPCom.2015.7150693

[3] SAHA, P., MITRA, D., PARUI, S. K. A frequency and polarization agile disc monopole wearable antenna for medical applications. Radioengineering, 2020, vol. 29, no. 1, p. 74-80. DOI: $10.13164 /$ re.2020.0074

[4] TONG, X., LIU, C., GUO, H., et al. A triple-mode reconfigurable wearable repeater antenna for WBAN applications. International Journal of $R F$ and Microwave Computer-Aided Engineering, 2018, vol. 29 , no. 3 , p. $1-8$. DOI: $10.1002 /$ mmce. 21615

[5] KIOURTI, A., COSTA, J. R., FERnANDES, C. A., et al. A broadband implantable and a dual-band on-body repeater antenna: Design and transmission performance. IEEE Transactions on Antennas and Propagation, 2014, vol. 62, no. 6, p. 2899-2908. DOI: $10.1109 /$ tap.2014.2310749

[6] BHATtACHARJEe, S., MAity, S., METYA, S. K., et al. Performance enhancement of implantable medical antenna using differential feed technique. International Journal of Engineering, Science and Technology, 2016, vol. 19, no. 1, p. 642-650. DOI: 10.1016/j.jestch.2015.09.001

[7] OKAN, T., AKÇAM, N. Wideband low cost FR4 epoxy based antenna with $\mathrm{H}$-shaped slot for $\mathrm{V}$-band applications. International Journal of RF and Microwave Computer-Aided Engineering, 2021, vol. 31, no. 2, p. 1-9. DOI: $10.1002 /$ mmce. 22348

[8] DOGANCI, E., UCAR, M. H. B., SONDAS, A. Preparation of a human skin-mimicking gels for in vitro measurements of the dual-band medical implant antenna. Journal of the Turkish Chemical Society Section A: Chemistry, 2016, vol. 3, no. 1, p. 583-596. DOI: $10.18596 /$ jotcsa. 72855

[9] SUKHIJA, S., SARIN, R. K. Design and performance of twosleeve low profile antenna for bio-medical applications. Journal of Electrical Systems and Information Technology, 2017, vol. 4, no. 1, p. 49-61. DOI: 10.1016/j.jesit.2016.10.013

[10] OKAN, T. A compact octagonal-ring monopole antenna for super wideband applications. Microwave and Optical Technology Letters, 2019, vol. 62, no. 3, p. 1237-1244. DOI: 10.1002/mop.32117

[11] PALANDOKEN, M. Compact bioimplantable MICS and ISM band antenna design for wireless biotelemetry applications. Radioengineering, 2017, vol. 26, no. 4, p. 917-923. DOI: 10.13164/re.2017.0917 
[12] SOONTORNPIPIT, P., FURSE, C. M., CHUNG, Y. C. Design of implantable microstrip antenna for communication with medical implants. IEEE Transactions on Microwave Theory and Techniques, 2004, vol. 52, no. 8, p. 1944-1951. DOI: $10.1109 /$ tmtt.2004.831976

[13] ASHOK KUMAR, S., SHANMUGANANTHAM, T. Design of implantable CPW fed monopole H-slot antenna for $2.45 \mathrm{GHz}$ ISM band applications. AEU - International Journal of Electronics and Communications, 2014, vol. 68, no. 7, p. 661-666. DOI: 10.1016/j.aeue.2014.02.010

[14] ASHOK KUMAR, S., SHANMUGANANTHAM, T. SASIKALA, G. Design and development of implantable CPW fed monopole U slot antenna at $2.45 \mathrm{GHz}$ ISM band for biomedical applications. Microwave and Optical Technology Letters, 2015, vol. 57, no. 7, p. 1604-1608. DOI: 10.1002/mop.29151

[15] SCARPELLO, M. L., KURUP, D., ROGIER, H., et al. Design of an implantable slot dipole conformal flexible antenna for biomedical applications. IEEE Transactions on Antennas and Propagation, 2011, vol. 59, no. 10, p. 3556-3564. DOI: 10.1109/tap.2011.2163761

[16] KARACOLAK, T., HOOD, A. Z., TOPSAKAL, E. Design of a dual-band implantable antenna and development of skin mimicking gels for continuous glucose monitoring. IEEE Transactions on Microwave Theory and Techniques, 2008, vol. 56, no. 4, p. 1001-1008. DOI: $10.1109 / \mathrm{tmtt} .2008 .919373$

[17] KIM, J., RAHMAT-SAMII, Y. Implanted antennas inside a human body: Simulations, designs, and characterizations. IEEE Transactions on Microwave Theory and Techniques, 2004, vol. 52, no. 8, p. 1934-1943. DOI: $10.1109 / \mathrm{tmtt} .2004 .832018$

[18] XIA, W., SAITO, K., TAKAHASHI, M., et al. Performances of an implanted cavity slot antenna embedded in the human arm. IEEE Transactions on Antennas and Propagation, 2009, vol. 57, no. 4, p. 894-899. DOI: $10.1109 /$ tap.2009.2014579

[19] MATHEW, J., ABRAHAM, M., MATHEW, T. Triple band printed modified bow-tie antenna for RFID reader/ISM applications. Procedia Computer Science, 2016, vol. 93, p. 48-52. DOI: $10.1016 /$ j.procs.2016.07.180
[20] HASHEMI, S., RASHED-MOHASSEL, J. Design and miniaturization of dual band implantable antennas. Biocybernetics and Biomedical Engineering, 2018, vol. 38, no. 4, p. 868-876. DOI: $10.1016 /$ j.bbe.2018.06.008

[21] SOONTORNPIPIT, P. A dual-band compact microstrip patch antenna for $403.5 \mathrm{MHz}$ and $2.45 \mathrm{GHz}$ on-body communications. Procedia Computer Science, 2016, vol. 86, p. 232-235. DOI: 10.1016/j.procs.2016.05.105

[22] MIRAN, M. M., ARIFIN, F. Design and performance analysis of a miniaturized implantable PIFA for wireless body area network applications. In International Conference on Robotics, Electrical and Signal Processing Techniques (ICREST). Dhaka (Bangladesh), 2019, p. 253-257. DOI: 10.1109/ICREST.2019.8644216

[23] BALANIS, C. A. Antenna Theory: Analysis and Design. New York: J. Wiley, 2005. ISBN-13: 978-0471667827

\section{About the Author ...}

Tayfun OKAN was born in Ankara, Turkey. He received the B.Sc. degree from Electrical and Electronics Engineering, Baskent University, Ankara, Turkey. He then received the M.S. and Ph.D. degrees from Electrical and Electronics Engineering Department of Gazi University in 2012 and 2018, respectively. He is currently working as an assistant professor in Electrical-Electronic Engineering Department, Gazi University, Ankara, Turkey. His research interests are electrically small antennas, microwave/millimeter wave components and subsystems, high frequency techniques, radiation pattern analysis and radar cross section calculations. 